\title{
Three new epigean representatives of Roncus L. Koch, 1873 (Neobisiidae, Pseudoscorpiones), from the Balkan Peninsula
}

\author{
Božidar P.M. Curčić, Srećko B. Ćurčić, Nina B. Curčić \& Slobodan E. Makarov \\ Institute of Zoology, Faculty of Science, University of Belgrade, Studentski Trg 16, YU-11000 Beograd, \\ Yugoslavia
}

Keywords: Roncus, Neobisiidae, pseudoscorpions, taxonomy, biogeography, Serbia, Balkan Peninsula

\begin{abstract}
Two species and one subspecies of Roncus L. Koch, 1873, new to science ( $R$. tintilin $\mathrm{n}$. sp., $R$. trojan $\mathrm{n}$. sp., and $\boldsymbol{R}$. trojan strahor $\mathrm{n}$. ssp.), collected in eastern and southeastern Serbia, Yugoslavia, are described, diagnostic characters are illustrated, and their distribution is given.

The possible establishment of two species groups of Roncus is discussed briefly in view of the importance of some diagnostic characters.
\end{abstract}

\section{Résumé}

Deux nouvelles espèces et une sous-espèce du genre Roncus $\mathbf{L}$. Koch, 1873 ( $R$. tintilin n. sp., $R$. trojan n. sp., et $R$. trojan strahor n. ssp.), recueillies dans l'est et le sud-est de la Serbie, Yougoslavie, sont décrites, leurs caractères diagnostiques sont illustrés, et leur répartition est décrite.

La possibilité d'établir deux groupes d'espèces de Roncus est brièvement discuté compte tenu de l'importance de quelques caractères diagnostiques.

\section{Introduction}

Four epigean species of Roncus L. Koch, 1873 (Neobisiidae), are presently known from Serbia, Yugoslavia: Roncus aff. lubricus L. Koch, 1873, is widely distributed in epigean habitats, but sometimes it occurs also in caves (Ćurčić, 1991); R. pannonius Curčić, Dimitrijević \& Karamata, 1992, from the village of Obrež, northern Serbia; $R$. jarilo Ćurčić, 1992, from the village of Asanovac
(Žitoradja), near Prokuplje, central Serbia; and $R$. svarozici Curčić, 1992, from the village of Jelovica, near Pirot, southeastern Serbia. All species inhabit leaf litter and humus.

In the present study, material from three samples of pseudoscorpions collected in 1989 and 1991 is examined. Specimens studied from Mt. Rtanj, near the village of Rujište, eastern Serbia, belong to a new species: Roncus tintilin $\mathrm{n}$. sp. The samples from Lepterija, near Soko Banja, and from the village of Poganovo, near Dimitrovgrad, both in southeastern Serbia, consist of two new taxa: Roncus trojan n. sp. and $R$. trojan strahor n. ssp., respectively. The taxa described in this paper are probably endemic and relict forms which inhabit epigean habitats in the eastern and southeastern parts of Serbia.

All specimens were mounted on slides in Swan's fluid (gum chloral medium) and deposited in the collection of the Institute of Zoology, Faculty of Science (Biology), University of Belgrade, Belgrade, Yugoslavia.

\section{Descriptive part}

Roncus tintilin B.P.M. Curčić, n. sp.

(Figs. 1-13; Table I)

Specimens examined. - Holotype $\sigma$, allotype $\odot, 4$ paratype $\sigma \circ, 6$ paratype $\& \%$, and one paratype tritonymph, from oak leaf litter and humus at the edge of a quarry near the restaurant "Šoferska Noć", Mt. Rtanj, near the village of Rujište, on road 
Soko Banja - Boljevac, eastern Serbia, Yugoslavia; 20 August 1991; B.P.M. Ćurčić, S.B. Ćurčić \& N.B. Curčić coll.

Description. - Epistome triangular and pointed (or slightly rounded apically; Figs. 1-3). Carapace longer than broad (Table I). One small eye on each carapace side (tapetum still visible). Setal formulae: $4+7+2+4+2+6=25,4+1+6+2+$ $4+2+6=25,4+8+2+4+2+6=26$, $4+6+2+4+2+6=24$ (female), $4+6+$ $2+4+2+6=24,4+6+2+4+2+7=$ $25,4+1+7+2+4+2+7=27,4+1+$ $7+2+4+2+6=26$ (male), and $4+6+2$ $+4+2+6=24$ (tritonymph). The basic pattern is, probably, $4+6+2+4+2+6=24$ setae. Preocular microsetae not developed.

Abdominal tergites $I-X$ smooth, entire, and uniseriate. Number of setae on tergite I (females) (values for males in parentheses): 6(6-8), tergite II 8-11 (8-11), tergite III 9-12 (11 or 12), tergite IV 11 or $12(11-13)$, tergite V $11-13(11$ or 12$)$, tergite VI $11-13(11-13)$, tergite VII 12 or $13(11$ or 12$)$, tergite VIII $11-13(10-12)$, tergite IX 11 or $12(11)$, and tergite $X 10$ or $11(10-12)$.

Female genital area: sternite II with 9 or 10 small, posterior and median setae in the form of an irregular field. Sternite III with 13-16 posterior setae and 3 microsetae along each stigma. Sternite IV with 8-11 marginal setae and 3 suprastigmal microsetae on either side. Male genital area: sternite II with 17-22 setae (of these, 9-11 setae grouped medially and 8-13 setae distributed along posterior margin). Sternite III with 4 (rarely 5 or 6 ) anterior setae, 11 or 12 posterior setae, and 3 microsetae along each stigma. Sternite IV with 9-12 anterior setae and 3 suprastigmal microsetae on either side. Sternites $\mathrm{V}-\mathrm{X}$ setation (females) (values for males in parentheses): $12-14$ (13-15), 14-18 (15-17), 15-17 (14 or 15$), 14-17(14-16), 14-16(14$ or 15$)$, and 14 or 15 (13 or 14), respectively. Twelfth abdominal segment with two pairs of small setae.

Galea low and rounded (Fig. 11). Cheliceral palm with 6 , movable finger with 1 seta. Cheliceral teeth of unequal form and size (Fig. 11). Flagellum of 8 (adult) or 7 blades (tritonymph), pinnate along their anterior margins.

Manducatory process with 4 long setae (Fig. 8).
Pedipalpal articles moderately elongate; trochanter with a small tubercle and some inconspicuous denticulations dorsally. Pedipalpal femur with distinct granulations; chelal palm inconspicuously granulated on its interior and lateral side (Figs. 9, 10). Pedipalpal tibia smooth. Fixed chelal finger with 49-53 (female), 52-57 (male), and 38 teeth (tritonymph), respectively; distal teeth pointed and asymmetrical, followed by small, closely-set, and square-cusped teeth proximally. Movable chelal finger with 50-56 (female), 51-56 (male), and 39 teeth (tritonymph); only distal teeth pointed and retroconical, other teeth rounded or square-cusped. Chelal fingers in general as long as chelal palm and shorter than carapace. Pedipalpal femur as long as carapace (Table I). Tiny microsetae proximal to $e b$ and esb absent; 4-6 microsetae distal to these trichobothria present (for abbreviations of setal names, see Beier, 1963).

Trichobothriotaxy: $e b, e s b, i b$, and $i s b$ on finger base; $i t, e t$, and est in proximal half of finger; ist in general equidistant from est and isb (rarely slightly closer either to est or is $b$ ). Seta $s b$ closer to $b$ than to $s t$, st closer to $t$ than to $s b$. For trichobothrial pattern, see Figs. 4-6.

Tibia IV, basitarsus IV, and telotarsus IV each with a single tactile seta (Fig. 7). For morphometric ratios and linear measurements, see Table $\mathbf{I}$.

Teratology. - In a single paratype male, tergites VII-X are anomalous: tergites VII and VIII fused on the left, and tergites VIII and IX fused on the right. As a consequence, tergal setae are missing on the left demi-tergite VII and on the right demitergite VIII. This aberration is a combination of multiple symphysomery (sclerite fusion) and hemimery (spiral alignment of segment halves).

Distribution. - Eastern Serbia, Yugoslavia, epigean (under stones, and in humus and leaf litter). Probably endemic to the Balkan Peninsula.

Remarks. - The present species is distinct from the epigean $R$. jarilo, from central Serbia, in the number of teeth on the movable chelal finger of males (51-56 vs. 42-46), the form of the pedipalpal podomeres (slightly elongate vs. more robust), the 

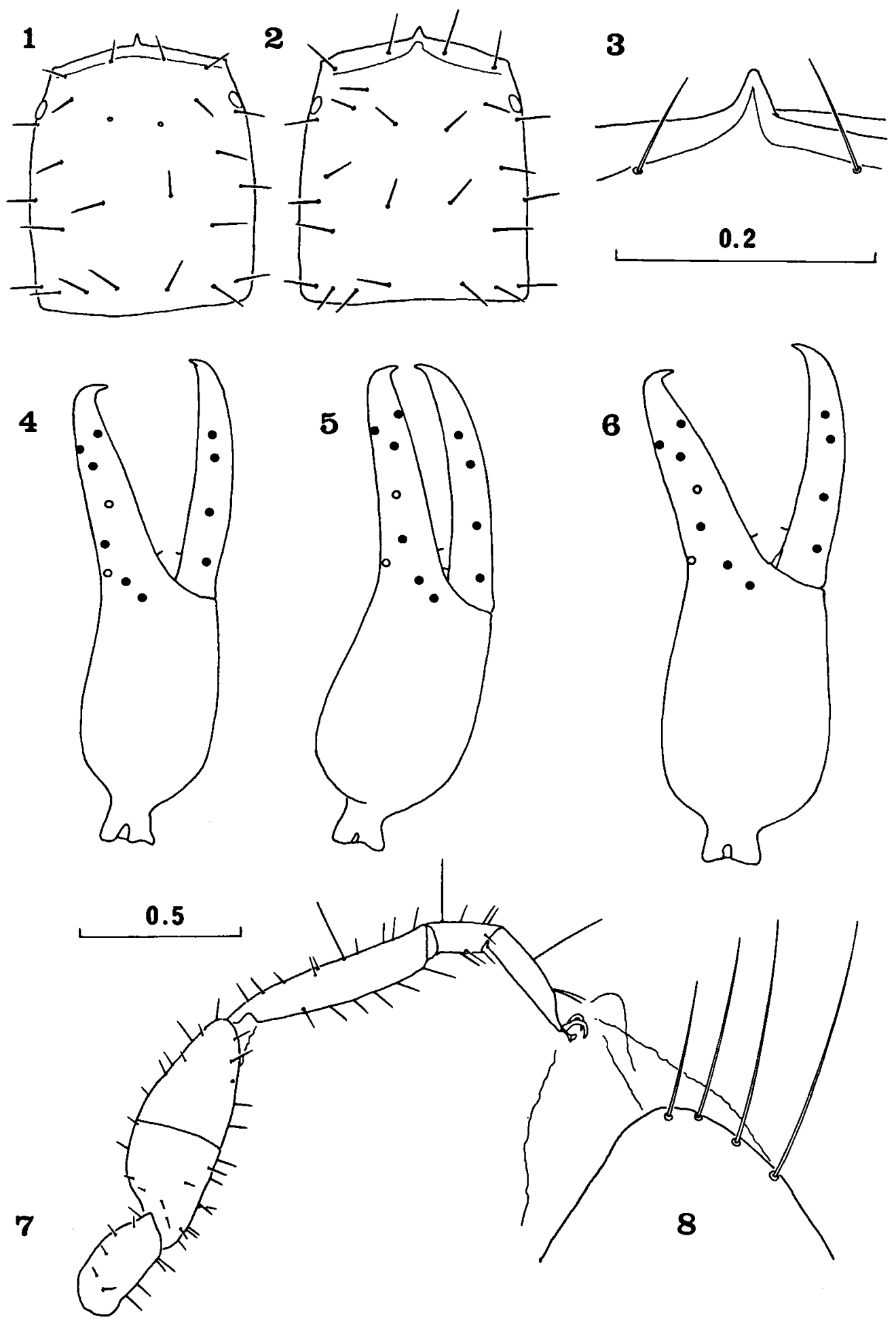

Figs. 1-8. Roncus tintilin Curcić, n. sp.: 1, carapace, $\sigma$ holotype; 2, carapace, $\odot$ allotype; 3, epistome, $\sigma$ holotype; 4, pedipalpal chela (trichobothrial pattern), $\sigma$ holotype; 5, pedipalpal chela (trichobothrial pattern), $\sigma$ paratype; 6, pedipalpal chela (trichobothrial pattern), $९$ allotype; 7 , leg IV, $\sigma$ holotype; 8, apex of pedipalpal coxa, $\odot$ allotype. Scales in $\mathrm{mm}$. 


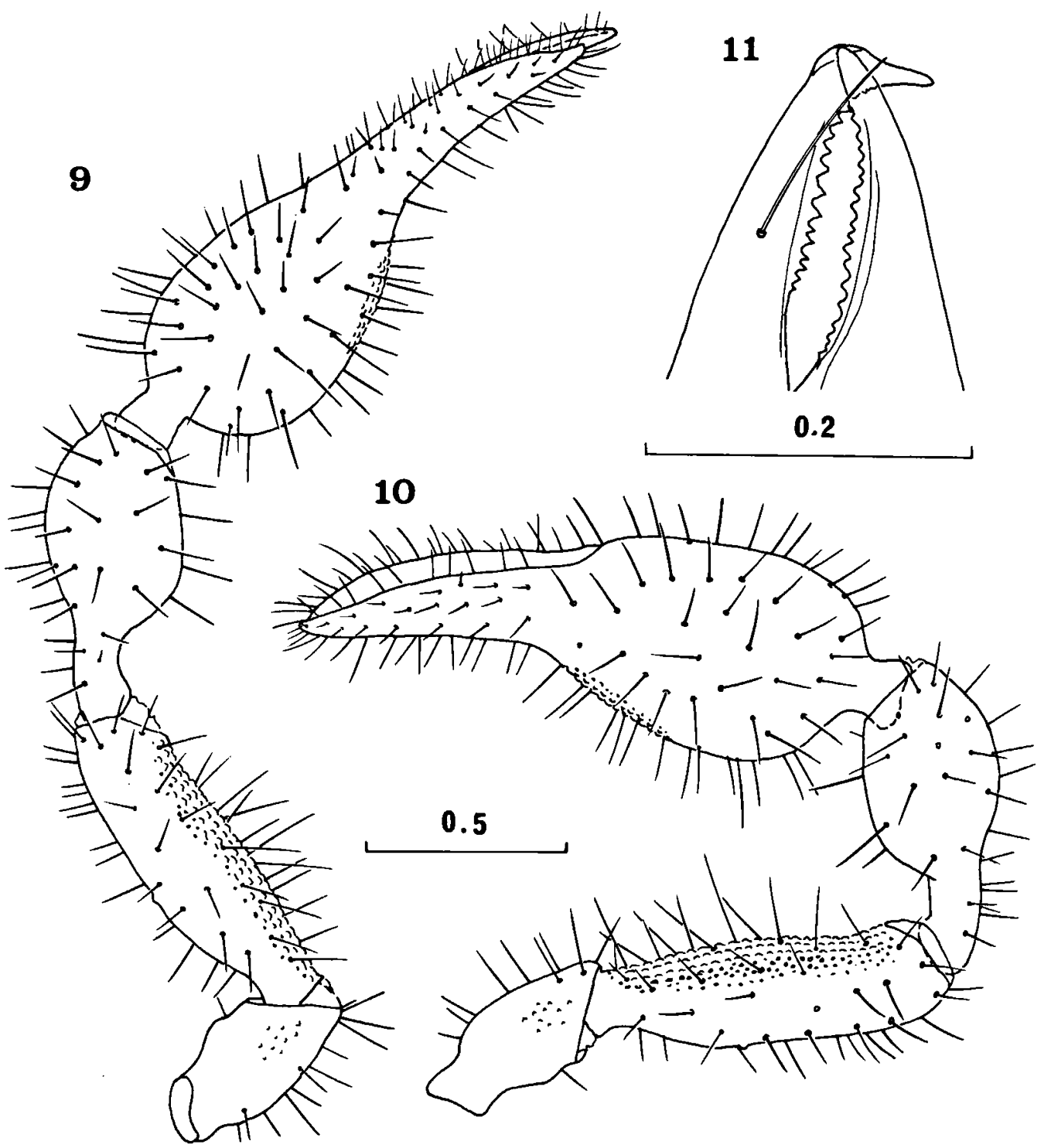

Figs. 9-11. Roncus tintilin Ćurčić, n. sp.: 9, pedipalp (trichobothria omitted), $\sigma$ holotype; 10, pedipalp (trichobothria omitted), $\$$ allotype; 11 , cheliceral fingers, $\$$ allotype. Scales in $\mathrm{mm}$.

position of the trichobothrium ist (equidistant from $i s b$ and est vs. closer to isb than to est ), the pedipalpal femur length in females $(0.82-0.91 \mathrm{~mm}$ vs. $0.67-0.775 \mathrm{~mm})$ and males $(0.82-0.905 \mathrm{~mm}$ vs. $0.57-0.71 \mathrm{~mm})$, and in the chelal finger length of the female $(0.69-0.87 \mathrm{~mm}$ vs. $0.58-0.64 \mathrm{~mm})$ and male $(0.71-0.75 \mathrm{~mm}$ vs. $0.49-0.64 \mathrm{~mm})$. To date, both species are known only from their type localities (in central and eastern Serbia, respectively).

$R$. tintilin $\mathrm{n}$. sp. is also distinct from the pheneti- cally most similar species, $R$. svarozici, from southeastern Serbia, by the number of teeth on the fixed chelal finger of males (52-57 vs. 58-61) and females (49-53 vs. 55-60), the number of teeth on the movable chelal finger of males (51-56 vs. 57-63), the presence/absence of the galea (present vs. almost lacking), the ratio of the chelal finger length to chelal palm length (chelal finger almost equal to chelal palm vs. chelal finger longer than chelal palm), the ratio of the pedipalpal femur 
Table I. Range in measurements (mm) of various structures, together with selected ratios, in Roncus tintilin n. sp. Abbreviations: trito = tritonymph, $\mathrm{TS}=$ tactile seta.

\begin{tabular}{|c|c|c|c|}
\hline Character & १ & $\sigma \sigma$ & trito. \\
\hline \multicolumn{4}{|l|}{ BODY } \\
\hline Length (1) & $3.10-3.58$ & $2.84-3.35$ & 2.21 \\
\hline \multicolumn{4}{|l|}{ CEPHALOTHORAX } \\
\hline Length (2) & $0.77-0.91$ & $0.795-0.88$ & 0.56 \\
\hline Breadth & $0.64-0.77$ & $0.63-0.79$ & 0.47 \\
\hline \multicolumn{4}{|l|}{ ABDOMEN } \\
\hline Length & $2.26-2.74$ & $2.02-2.54$ & 1.65 \\
\hline Breadth & $1.06-1.23$ & $0.96-0.79$ & 0.96 \\
\hline \multicolumn{4}{|l|}{ CHELICERAE } \\
\hline Length (3) & $0.49-0.58$ & $0.48-0.51$ & 0.39 \\
\hline Breadth (4) & $0.25-0.305$ & $0.24-0.27$ & 0.20 \\
\hline Length of movable finger (5) & $0.34-0.39$ & $0.34-0.35$ & 0.27 \\
\hline Ratio $3 / 5$ & $1.43-1.53$ & $1.41-1.46$ & 1.44 \\
\hline Ratio 3/4 & $1.69-2.20$ & $1.85-2.00$ & 1.95 \\
\hline Length of galea & 0.01 & 0.01 & 0.01 \\
\hline \multicolumn{4}{|l|}{ PEDIPALPS } \\
\hline Length with coxa (6) & $3.97-4.57$ & $4.09-4.335$ & 2.82 \\
\hline Ratio 6/1 & $1.13-1.45$ & $1.28-1.44$ & 1.28 \\
\hline Length of coxa & $0.61-0.71$ & $0.64-0.71$ & 0.51 \\
\hline Length of trochanter & $0.47-0.55$ & $0.49-0.53$ & 0.36 \\
\hline Length of femur (7) & $0.82-0.91$ & $0.82-0.905$ & 0.51 \\
\hline Breadth of femur (8) & $0.24-0.27$ & $0.24-0.26$ & 0.18 \\
\hline Ratio $7 / 8$ & $3.22-3.58$ & $3.19-3.50$ & 2.83 \\
\hline Ratio $7 / 2$ & $0.96-1.08$ & $1.00-1.05$ & 0.91 \\
\hline Length of tibia (9) & $0.67-0.78$ & $0.70-0.75$ & 0.45 \\
\hline Breadth of tibia (10) & $0.31-0.36$ & $0.315-0.34$ & 0.23 \\
\hline Ratio $9 / 10$ & $2.055-2.23$ & $2.205-2.22$ & 1.96 \\
\hline Length of chela (11) & $1.40-1.65$ & $1.42-1.50$ & 0.99 \\
\hline Breadth of chela (12) & $0.42-0.49$ & $0.43-0.48$ & 0.315 \\
\hline Ratio $11 / 12$ & $3.04-4.07$ & $3.08-3.30$ & 3.14 \\
\hline Length of chelal palm (13) & $0.71-0.84$ & $0.70-0.75$ & 0.50 \\
\hline Ratio $13 / 12$ & $1.53-2.10$ & $1.54-1.65$ & 1.59 \\
\hline Length of chelal finger (14) & $0.69-0.87$ & $0.71-0.75$ & 0.49 \\
\hline Ratio $14 / 13$ & $0.95-1.035$ & $1.00-1.03$ & 0.98 \\
\hline \multicolumn{4}{|l|}{ LEG IV } \\
\hline Total length & $2.655-3.00$ & $2.675-2.99$ & 1.85 \\
\hline Length of coxa & $0.45-0.47$ & $0.425-0.47$ & 0.30 \\
\hline Length of trochanter (15) & $0.315-0.38$ & $0.34-0.36$ & 0.23 \\
\hline Breadth of trochanter (16) & $0.15-0.17$ & $0.15-0.17$ & 0.14 \\
\hline Ratio $15 / 16$ & $1.89-2.31$ & $2.12-2.33$ & 1.64 \\
\hline Length of femur (17) & $0.69-0.795$ & $0.71-0.82$ & 0.51 \\
\hline Breadth of femur (18) & $0.26-0.31$ & $0.26-0.29$ & 0.195 \\
\hline Ratio $17 / 18$ & $2.42-2.925$ & $2.73-2.87$ & 2.615 \\
\hline Length of tibia (19) & $0.64-0.75$ & $0.62-0.72$ & 0.40 \\
\hline Breadth of tibia (20) & $0.12-0.14$ & $0.12-0.13$ & 0.11 \\
\hline Ratio $19 / 20$ & $5.21-5.615$ & $5.17-5.67$ & 3.64 \\
\hline Length of basitarsus (21) & $0.21-0.25$ & $0.22-0.24$ & 0.16 \\
\hline Breadth of basitarsus (22) & $0.09-0.11$ & 0.10 & 0.075 \\
\hline Ratio $21 / 22$ & $2.27-2.50$ & $2.20-2.40$ & 2.13 \\
\hline Length of telotarsus (23) & $0.35-0.39$ & $0.36-0.40$ & 0.25 \\
\hline Breadth of telotarsus (24) & $0.085-0.10$ & $0.08-0.09$ & 0.075 \\
\hline Ratio $23 / 24$ & $3.80-4.33$ & $4.22-5.00$ & 3.33 \\
\hline TS ratio tibia IV & $0.52-0.63$ & $0.57-0.595$ & 0.44 \\
\hline TS ratio basitarsus IV & $0.16-0.21$ & $0.16-0.215$ & 0.15 \\
\hline TS ratio telotarsus IV & $0.33-0.37$ & $0.29-0.38$ & 0.30 \\
\hline
\end{tabular}


length to carapace length (femur longer than carapace vs. femur equal to carapace), the form of the pedipalpal articles (more elongated vs. more robust), the length of the pedipalpal femur of females $(0.82-0.91 \mathrm{~mm}$ vs. $0.78-0.79 \mathrm{~mm})$, and the pedipalpal tibia length of males $(0.70-0.75 \mathrm{~mm}$ vs. 0.60-0.65 mm).

Etymology. - After Tintilin, the name of the ancient Serbian demon guarding mines (Čajkanović, 1941).

Roncus trojan B.P.M. Curčić, n. sp.

Figs. 12-24; Table II)

Specimens examined. - Holotype $\sigma^{\circ}$, allotype $९, 11$ paratype $\sigma^{\circ} \sigma$, and 6 paratype $q \propto$, from leaf litter and humus in a mixed oak and beech forest, Lepterija, near Soko Banja, southeastern Serbia, Yugoslavia; August 1991; B.P.M. Ćurčić, S.B. Curčić, and N.B. Curčić coll.

Description. - Epistome pointed and triangular (Figs. 12, 13). Carapace longer than broad (Table II). One small eye on each carapace side. Setal formulae: $4+6+2+4+2+6=24,4+1+$ $6+2+4+2+6=25$ (female), $4+6+2+$ $4+2+2+6=26$, and $4+6+2+4+2+$ $6=24$ (male). The basic pattern is, probably, $4+$ $6+2+4+2+6=24$ setae. Preocular microsetae lacking.

Abdominal tergites I-X smooth, uniseriate and entire. Number of setae on tergite I (females) (values for males in parentheses) 6 (6), tergite II 6-9 (7 or 8$)$, tergite III $9-12(9-11)$, tergite IV 10-12 (10 or 11), tergite V 10-12 (10-12), tergite VI 10 or 11 (10 or 11$)$, tergite VII $9-11$ (10 or 11$)$, tergite VIII 11 or $12(10-12)$, tergite IX $11(9-11)$, and tergite $X 10$ or 11 ( 9 or 10$)$.

Female genital area: sternite II with 7 or 8 setae in the form of two barely distinguishable groups; sternite III with 11 or 12 posterior setae and 3 (rarely 4) microsetae along each stigma; sternite IV with 8 or 9 posterior setae, and 3 microsetae along each stigmatic plate. Male genital area: sternite II with 12 or 13 posterior and median setae; sternite III with 4 anterior, 10 or 11 posterior setae, and 3 microsetae on either side; sternite IV with 9 or 10 setae and 3 microsetae along either stigma. Sternites $\mathrm{V}-\mathrm{X}$ setation (females) (values for males in parentheses): 13-15 (13-15), 14-16 (13-16), 15 or $16(12-15), 14-16(13-15), 12-15(13-15)$, and 13 (12 or 13) setae, respectively. Twelfth abdominal segment with two pairs of small setae.

Cheliceral spinneret (galea) small and low (Fig. 14). Cheliceral palm with 6 setae, movable finger with 1 seta. Cheliceral teeth of unequal form and size (Fig. 14). Flagellum of 8 anteriorly pinnate blades.

Manducatory process with 4 long setae. Pedipalpal articles moderately elongate; trochanter with some inconspicuous denticulations dorsally and a small interior tubercle. Pedipalpal femur with distinct granulations; chelal palm granulated both extero- and intero-laterally, pedipalpal tibia smooth (Figs. 22-24). Fixed chelal finger with 54-63 (female) and 51-63 teeth (male); distal teeth pointed and asymmetrical, followed by small, closely-set, and square-cusped or rounded teeth proximally. Movable chelal finger with 54-63 (female) and 56-63 teeth (male); only distal teeth pointed and retroconical, other teeth squarecusped or rounded. Chelal fingers longer than chelal palm and only slightly longer than carapace. Pedipalpal femur longer than carapace (Table II).

Tiny microsetae (1-3) proximal to $e b$ and $e s b$ present; chelal palm with 3-5 microsetae distal to these trichobothria (Figs. 20, 21).

Trichobothriotaxy: $e b, e s b, i b$, and $i s b$ on finger base; it, et, and est in proximal finger half; ist slightly closer to est than to isb. Seta $s b$ equidistant from $b$ and $s t$, respectively. For trichobothrial patterns, see Figs. 15 and 16.

Leg IV: tibia, basitarsus, and telotarsus each with a single tactile seta (Figs. 17, 18). For morphometric ratios and linear measurements, see Table II).

Distribution. - Southeastern Serbia, Yugoslavia; epigean (in leaf litter and humus).

Remarks. $-\boldsymbol{R}$. trojan $\mathrm{n}$. sp. is easily distinguished from $R$. pannonius (its phenetically most similar species sharing the presence of microsetae proximal to $e b$ and $e s b$ ), from northern Serbia, by the body 
12

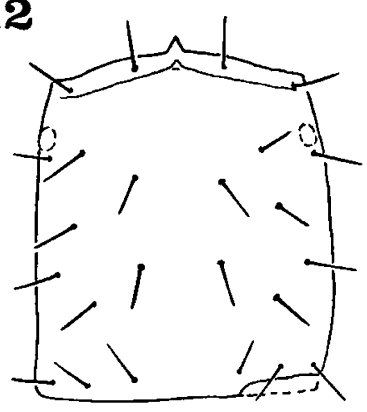

13

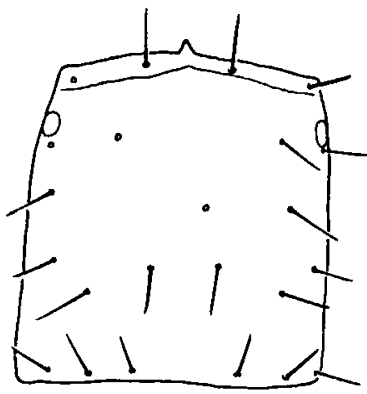

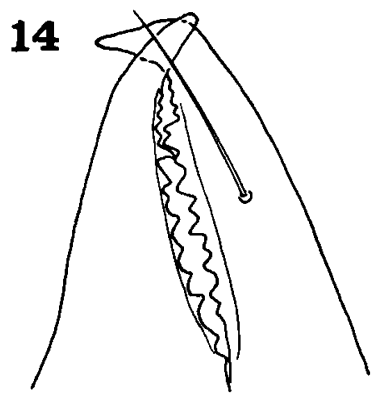
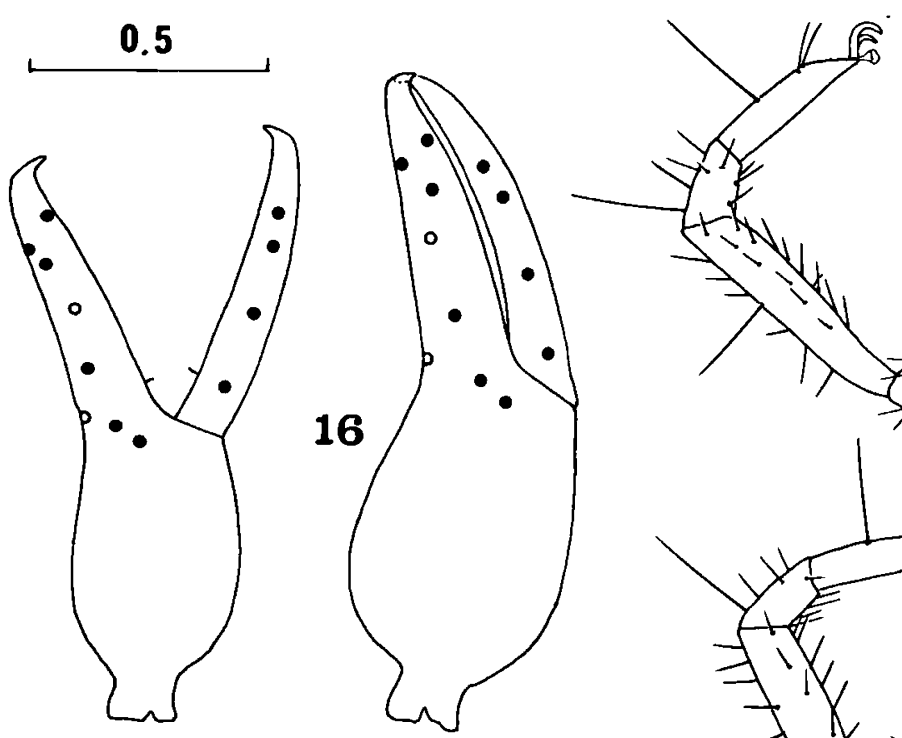

17

15

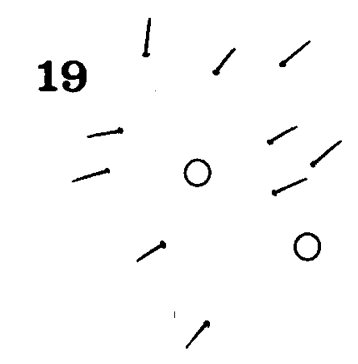

20

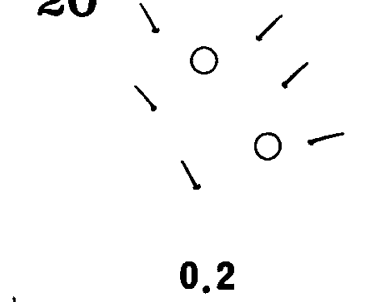<smiles>COC(C)C</smiles>

$\mathrm{O}$

$\searrow$

\section{8}

Figs. 12-21. Roncus trojan Curčić, n. sp.: 12, carapace, $\sigma^{*}$ holotype; 13, carapace, $\uparrow$ allotype; 14, cheliceral fingers, $\sigma$ holotype; 15 , pedipalpal chela (trichobothrial pattern), $\sigma$ holotype; 16, pedipalpal chela (trichobothrial pattern), $\odot$ allotype; 17, leg IV, $\sigma^{\circ}$ holotype; 18 , leg IV, $q$ allotype; 19, microsetae proximal to $e b$ and es $b$, $\$$ allotype; 20, microsetae proximal to eb and esb, $\sigma^{\circ}$ holotype; 21 , microsetae proximal to $e b$ and $e s b, \sigma$ holotype. Scales in $\mathrm{mm}$. 


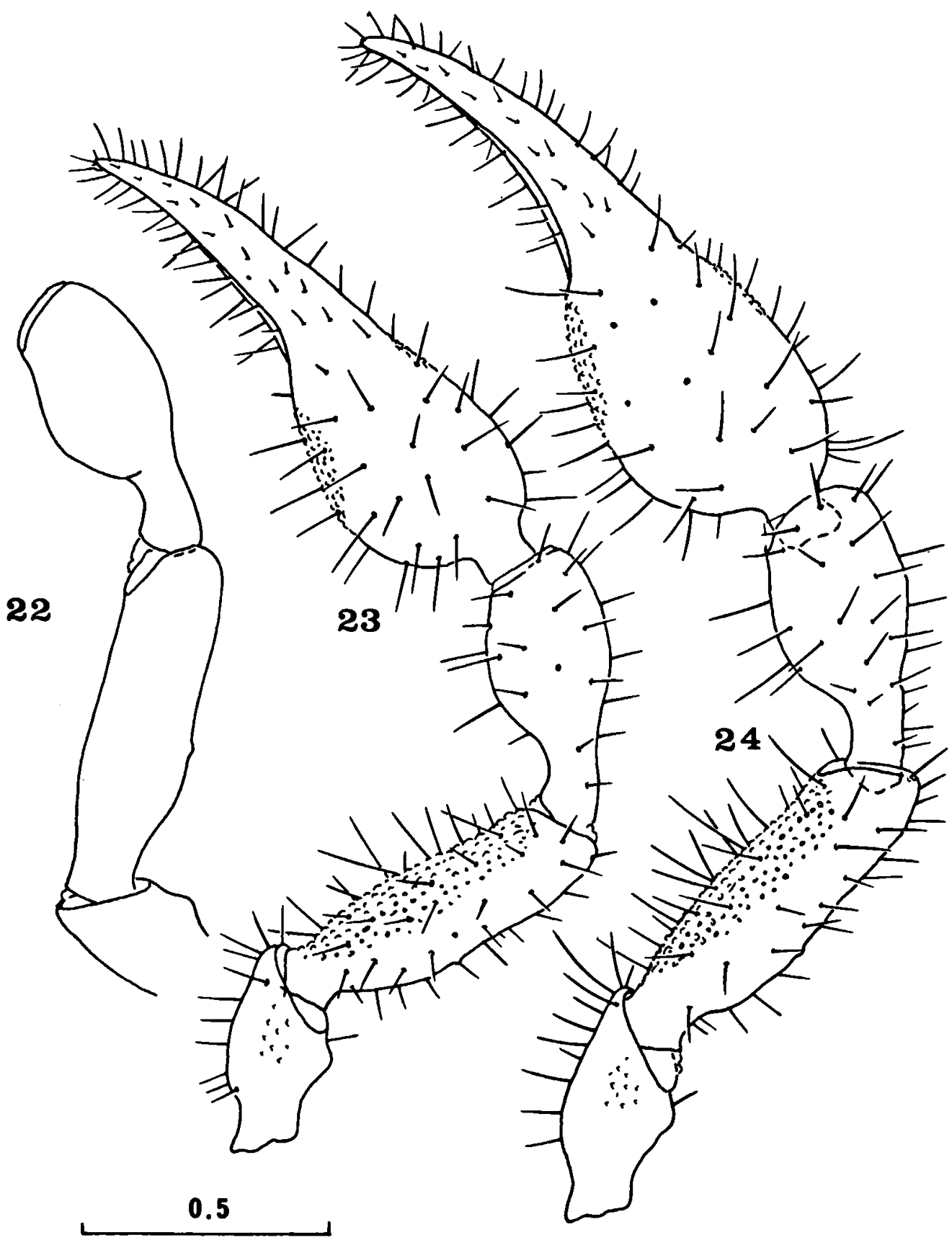

Figs. 22-24. Roncus trojan Ćurcić, n. sp.: 22, pedipalpal femur and tibia, o holotype; 23, pedipalp (trichobothria omitted), $\sigma$ holotype; 24 , pedipalp (trichobothria omitted), $\&$ allotype. Scale in $\mathrm{mm}$.

size (smaller vs. greater), the position of the trichobothrium $s b$ (equidistant from $b$ and $s t$ vs. slightly closer to $b$ than to $s t$ ), the form of the chelal palm (more elongate vs. more robust), the presence/absence of the extero-lateral granulations on the chelal palm (absent vs. present), the form of the basal part of the pedipalpal femur ("Femur Stiel" sensu Beier, 1963) (shorter and more robust vs. longer and more elongate), the shape of the chelal palm (elongate vs. ovate), and the ratio of the 
pedipalpal femur length to carapace length in both males $(1.195-1.39$ vs. $0.925-1.09)$ and females (1.255-1.42 vs. 0.91-1.04). Currently, this new species is known only from the type locality.

Etymology. - In Serbian mythology, Trojan is the great chthonian god (Čajkanović, 1941).

Roncus trojan strahor B.P.M. Curčić, n. ssp. (Figs. 25-33; Table II)

Specimens examined. - Holotype $\sigma$, and 16 paratype $\sigma \sigma^{\circ}$, from oak leaf litter and humus, Poganovski Manastir, village of Poganovo, near Dimitrovgrad, southeastern Serbia, Yugoslavia; 14 July 1989; B.P.M. Curčić, R.N. Dimitrijević, and O.S. Karamata coll.

Description. - Carapace longer than broad (Table II). Epistome triangular and pointed (Fig. 25). One small eye-spot on each side of carapace. Preocular microsetae not developed. Setal formulae: $4+1+$ $7+2+4+2+6=26,4+6+4+2+6=$ 22 , and $4+6+2+4+2+6=24$. The basic pattern is, probably, $4+6+2+4+2+6=24$.

Abdominal tergites $\mathrm{I}-\mathrm{X}$ smooth, entire, and uniseriate. Tergite I with 6 setae (numbers of setae gradually increasing on more posterior tergites, with a maximum of $10-12$ setae from tergite $V$ onwards); tergite II with 8-9 setae; tergites III-V each with 10 or 11 setae; tergite VI with $10-12$ setae; tergite VII with 10 or 11 setae; tergite VIII with 11 or 12 setae; tergite IX with 11 setae; and tergite $X$ with 10 or 11 setae.

Female genital area unknown. Male genital area: sternite II with 11-17 posterior and median setae (of these, 5-8 setae grouped in the form of a triangle, and the remainder present on posterior sternal margin). Sternite III with 4 (rarely 5) anterior setae, 10 or 11 posterior setae, and 3 suprastigmatic microsetae on either side. Sternite IV with 9 or 10 setae, and 3 small setae along each stigmatic plate. Sternite V with 14 or 15 , sternite VI with $13-15$, sternite VII with 13-16, sternite VIII with 13-15, and sternites IX and X each with 13 or 14 setae. Anal papilla with 2 pairs of small setae.

Cheliceral spinneret (galea) low and rounded (Fig. 26). Cheliceral palm with 6 setae, movable finger with 1 seta. Flagellum eight-bladed, characteristic of the genus Roncus.

Manducatory process with 4 long and acuminate setae (Fig. 27); trochanter with a small tubercle and some inconspicuous denticulations. Pedipalpal articles slightly elongate (Fig. 30); femur with interolateral granulations, and one small tubercle exterolaterally. Chelal palm with inconspicuous granulations on its intero-lateral side. Pedipalpal tibia smooth. Fixed chelal finger with 51-54 teeth; only distal teeth slightly asymmetrical and pointed, other teeth closely set, small, and retroconical. Movable chelal finger with 52-61 teeth; only distal teeth triangular, other teeth rounded or squarecusped. Chelal fingers longer than chelal palm, but shorter than carapace. Pedipalpal femur as long as carapace. Tiny microsetae (1-3) developed proximal to $e b$ and $e s b ; 3-5$ microsetae distal and lateral to these two trichobothria (Figs. 32, 33).

Trichobothriotaxy: $e b, e s b, i b$, and $i s b$ on finger base; $i t$, et, and est in proximal half of finger. Seta ist equidistant from est and isb. Trichobothrial patterns as illustrated in Figs. 28 and 29.

Leg IV: tibia, basitarsus, and telotarsus each with a single tactile seta (Fig. 31). For linear measurements and morphometric ratios, see Table II.

Teratology. - In a single male, the right cheliceral flagellum is anomalous. It consists of 10 blades (instead of 8); in addition, one median flagellar blade is thickened and shorter than other blades. The left flagellum is normal.

Distribution. - Southeastern Serbia, Yugoslavia; epigean. Probably endemic and relict form.

Remarks. - In spite of the fact that the majority of morphometric ratios and linear measurements of the nominal subspecies ( $R$. trojan trojan) and $R$. trojan strahor $\mathrm{n}$. ssp. are either very close, or their values overlap, there exist a number of features which are distinct in both subspecies. Thus, the nominal subspecies differs from $R$. trojan strahor n. ssp. in the ratio of pedipalpal femur length to carapace length $(0.93-1.06$ vs. $1.195-1.39)$, the body size (greater vs. smaller), the number of teeth on the chelal fingers (identical on both fingers vs. 

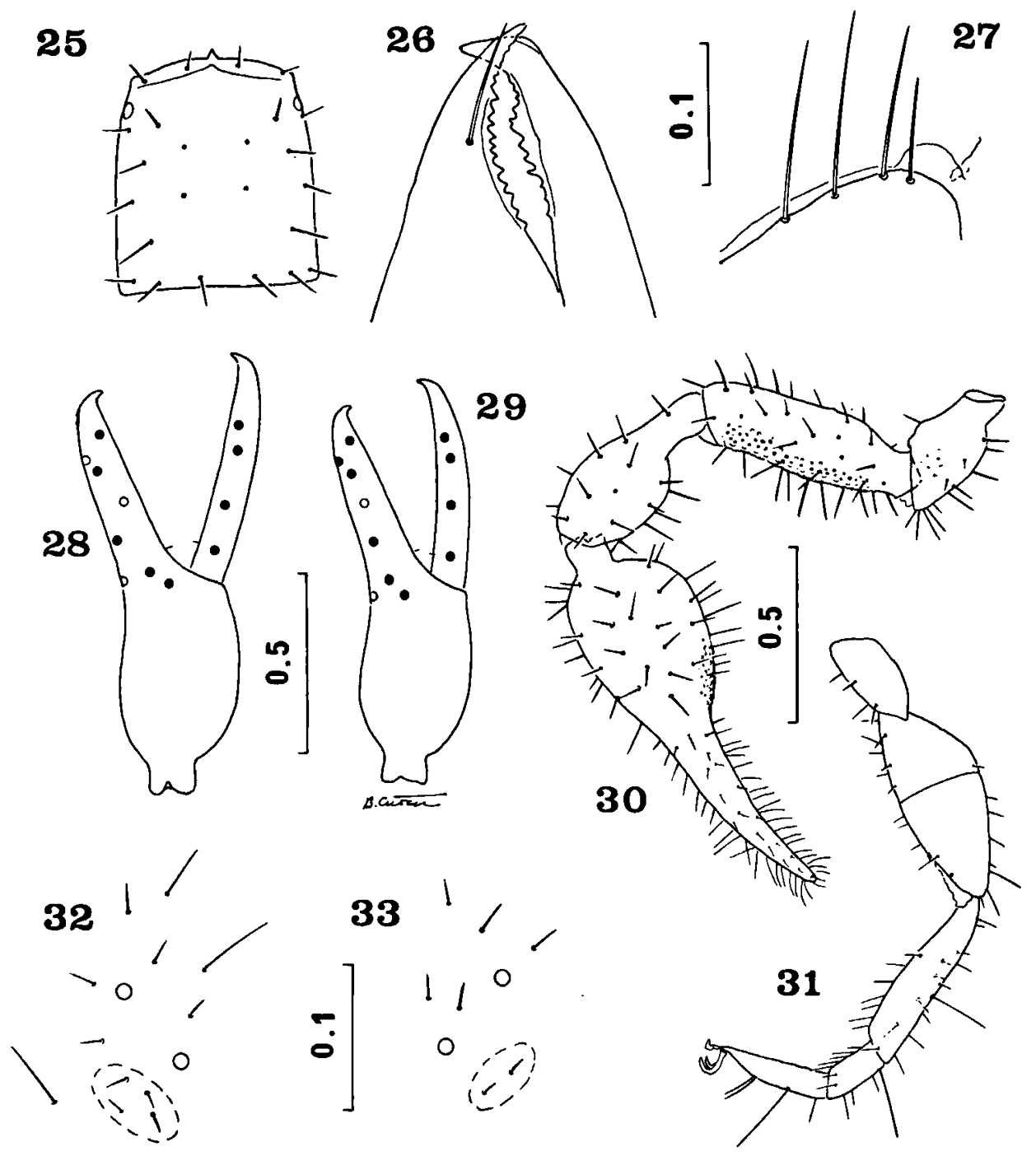

Figs. 25-33. Roncus trojan strahor Curxić, n. ssp.: 25, carapace, $\sigma$ holotype; 26, cheliceral fingers, $\sigma$ holotype; 27, apex of pedipalpal coxa, $\sigma$ holotype; 28, pedipalpal chela (trichobothrial pattern), $\sigma$ holotype; 29, pedipalpal chela (trichobothrial pattern), $\sigma$ paratype; 30, pedipalp (trichobothria omitted), $\sigma$ holotype; 31, leg IV, $\sigma$ holotype; 32, microsetae proximal to eb and esb, $\sigma$ holotype; 33 , microsetae proximal to $e b$ and $e s b, \sigma$ paratype. Scales in $\mathrm{mm}$.

fewer teeth on the fixed chelal finger), the number of teeth on the fixed chelal finger (more vs. less), the presence/absence of the exterior and lateral granulations on the chelal palm (present vs. absent), the shape of the pedipalpal tibia (more elongate vs. less elongate), and the length of telotarsus IV of males $(0.34-0.38 \mathrm{~mm}$ vs. $0.29-0.34 \mathrm{~mm})$.

Etymology. - In Serbian mythology, Strahor is one of the great chthonian deities (Stratimirović, 1936).

\section{Remarks}

The discovery of the described representatives of Roncus in Serbia supports the fact that the taxonomy of this genus is still far from being complete (Ćurčić, 1991, 1992a, 1992b; Ćurčić et al., 1992). The variety of cave-dwelling species of Roncus, described elsewhere by Curčić (1991), offers further proof that this genus is presently subjected to intensive radiation, or divergent differentiation into new 
Table II. Range in measurements (mm) of various structures, together with selected ratios, in Roncus trojan n. sp. and $R$. trojan strahor $\mathrm{n}$. ssp. Abbreviation: TS = tactile seta.

\begin{tabular}{|c|c|c|c|}
\hline \multirow[t]{2}{*}{ Character } & \multicolumn{2}{|c|}{ R. trojan trojan } & \multirow{2}{*}{$\begin{array}{l}\text { R. trojan strahor } \\
\sigma^{\circ} \sigma\end{array}$} \\
\hline & \% & $\sigma \sigma$ & \\
\hline \multicolumn{4}{|l|}{ BODY } \\
\hline Length (1) & $2.51-3.215$ & $2.415-3.07$ & $1.97-2.86$ \\
\hline \multicolumn{4}{|l|}{ CEPHALOTHORAX } \\
\hline Length (2) & $0.67-0.76$ & $0.67-0.81$ & $0.60-0.73$ \\
\hline Breadth & $0.58-0.63$ & $0.50-0.65$ & $0.51-0.57$ \\
\hline \multicolumn{4}{|l|}{ ABDOMEN } \\
\hline Length & $1.715-2.26$ & $1.78-2.33$ & $1.37-2.13$ \\
\hline Breadth & $0.82-1.13$ & $0.86-1.10$ & $0.78-1.00$ \\
\hline \multicolumn{4}{|l|}{ CHELICERAE } \\
\hline Length (3) & $0.41-0.48$ & $0.38-0.445$ & $0.36-0.41$ \\
\hline Breadth (4) & $0.22-0.25$ & $0.195-0.23$ & $0.18-0.22$ \\
\hline Length of movable finger (5) & $0.29-0.33$ & $0.25-0.325$ & $0.22-0.29$ \\
\hline Ratio $3 / 5$ & $1.37-1.48$ & $1.36-1.56$ & $1.36-1.76$ \\
\hline Ratio $3 / 4$ & $1.84-2.09$ & $1.77-2.05$ & $1.82-2.05$ \\
\hline Length of galea & 0.01 & 0.01 & 0.01 \\
\hline \multicolumn{4}{|l|}{ PEDIPALPS } \\
\hline Length with coxa (6) & $3.585-3.82$ & $3.37-3.79$ & $3.01-3.46$ \\
\hline Ratio 6/1 & $1.15-1.51$ & $1.20-1.42$ & $1.15-1.53$ \\
\hline Length of coxa & $0.48-0.60$ & $0.51-0.54$ & $0.45-0.51$ \\
\hline Length of trochanter & $0.425-0.48$ & $0.39-0.44$ & $0.37-0.42$ \\
\hline Length of femur (7) & $0.73-0.795$ & $0.67-0.75$ & $0.61-0.69$ \\
\hline Breadth of femur (8) & $0.21-0.24$ & $0.20-0.23$ & $0.18-0.21$ \\
\hline Ratio 7/8 & $3.24-3.57$ & $3.27-3.55$ & $3.13-3.63$ \\
\hline Ratio $7 / 2$ & $1.255-1.42$ & $1.195-1.39$ & $0.93-1.06$ \\
\hline Length of tibia (9) & $0.58-0.64$ & $0.535-0.63$ & $0.49-0.58$ \\
\hline Breadth of tibia (10) & $0.26-0.30$ & $0.24-0.28$ & $0.22-0.25$ \\
\hline Ratio $9 / 10$ & $2.03-2.26$ & $2.14-2.38$ & $1.82-2.39$ \\
\hline Length of chela (11) & $1.255-1.42$ & $1.195-1.39$ & $1.06-1.27$ \\
\hline Breadth of chela (12) & $0.37-0.44$ & $0.34-0.40$ & $0.30-0.36$ \\
\hline Ratio $11 / 12$ & $3.24-3.45$ & $3.27-3.705$ & $3.21-3.70$ \\
\hline Length of chelal palm (13) & $0.565-0.67$ & $0.53-0.64$ & $0.48-0.58$ \\
\hline Ratio $13 / 12$ & $1.46-1.64$ & $1.465-1.735$ & $1.44-1.70$ \\
\hline Length of chelal finger (14) & $0.69-0.75$ & $0.64-0.75$ & $0.58-0.69$ \\
\hline Ratio $14 / 13$ & $1.11-1.23$ & $1.135-1.31$ & $1.16-1.34$ \\
\hline \multicolumn{4}{|l|}{ LEG IV } \\
\hline Total length & $2.43-2.73$ & $2.385-2.70$ & $2.095-2.46$ \\
\hline Length of coxa & $0.39-0.43$ & $0.35-0.44$ & $0.315-0.40$ \\
\hline Length of trochanter (15) & $0.28-0.35$ & $0.29-0.34$ & $0.25-0.30$ \\
\hline Breadth of trochanter (16) & $0.13-0.16$ & $0.14-0.17$ & $0.12-0.14$ \\
\hline Ratio $15 / 16$ & $2.03-2.33$ & $1.97-2.36$ & $1.93-2.42$ \\
\hline Length of femur (17) & $0.63-0.72$ & $0.61-0.71$ & $0.55-0.64$ \\
\hline Breadth of femur (18) & $0.24-0.28$ & $0.23-0.27$ & $0.205-0.26$ \\
\hline Ratio $17 / 18$ & $2.52-2.82$ & $2.33-2.83$ & $2.40-2.76$ \\
\hline Length of tibia (19) & $0.57-0.63$ & $0.535-0.63$ & $0.49-0.57$ \\
\hline Breadth of tibia (20) & $0.11-0.13$ & $0.11-0.13$ & $0.09-0.12$ \\
\hline Ratio $19 / 20$ & $4.85-5.45$ & $4.46-5.45$ & $4.42-5.44$ \\
\hline Length of basitarsus (21) & $0.22-0.24$ & $0.205-0.23$ & $0.18-0.21$ \\
\hline Breadth of basitarsus (22) & $0.08-0.10$ & $0.08-0.09$ & $0.07-0.085$ \\
\hline Ratio $21 / 22$ & $2.40-2.75$ & $2.41-2.625$ & $2.31-2.71$ \\
\hline Length of telotarsus (23) & $0.34-0.38$ & $0.34-0.38$ & $0.29-0.34$ \\
\hline Breadth of telotarsus (24) & $0.08-0.09$ & $0.07-0.08$ & $0.07-0.08$ \\
\hline Ratio $23 / 24$ & $4.22-4.625$ & $4.25-5.43$ & $3.94-4.40$ \\
\hline TS ratio tibia IV & $0.58-0.61$ & $0.525-0.54$ & $0.51-0.61$ \\
\hline TS ratio basitarsus IV & $0.19-0.23$ & $0.17-0.24$ & $0.155-0.25$ \\
\hline TS ratio telotarsus IV & $0.35-0.39$ & $0.31-0.44$ & $0.34-0.40$ \\
\hline
\end{tabular}


species. Furthermore, the diversity of Roncus representatives in the Balkan regions bordering on Serbia (Ćurčić, 1984; Curčić \& Beron, 1981), compared to the same feature in other areas, points to the Balkan Peninsula as a centre of origin and genesis of numerous forms of the genus. In addition, the occurrence of numerous Roncus species with extremely limited distribution areas demonstrates their endemic nature.

With regard to a single diagnostic character (presence/absence of microsetae proximal to $e b$ and $e s b$ ), it should be noted that this feature is present in $R$. pannonius and $R$. trojan $\mathrm{n}$. sp., and virtually absent in $R$. jarilo and $R$. tintilin $\mathrm{n}$. sp., all from Serbia. However, these microsetae are missing in the cave-dwelling species of the genus which inhabit this region (Curčić, 1992a, 1992b). Therefore, it is possible that the presence or absence of this character may be useful in distinguishing representatives of two species groups, which we designate here as the "Roncus lubricus" (microsetae present) and " $R$. parablothroides" group (microsetae absent), respectively. It seems that both groups are widespread in Europe (Ćurčić et al., 1992); however, their precise taxonomic and biogeographic features are insufficiently known. Therefore, this problem remains one of the main goals for future research.

\section{Acknowledgements}

Grateful thanks are due to two anonymous reviewers for their constructive criticism of the manuscript.
Support for fieldwork was received from the Serbian Ministry of Science and Technology, Grant 0324. This work was also supported by the "Beobanka" - Belgrade and by the Serbian Academy of Sciences and Arts.

\section{References}

Beier, M., 1963. Ordnung Pseudoscorpionidea (Afterskorpione). Bestimmungsbücher zur Bodenfauna Europas, 1: 1-320 (Akademie-Verlag, Berlin).

Cajkanović, V., 1941. O srpskom vrhovnom bogu. Acad. Serbe Sci. Arts, Belgrade Éd. spéc., 122; Acta philos. philol., 34: 1-193.

Curčić, B.P.M., 1984. On two new species of Roncus L. Koch, 1873, from Macedonia (Arachnida: Pseudoscorpiones: Neobisiidae). Senckenbergiana biol., 65: 97-104.

Curčić, B.P.M., 1991. A new species of the genus Roncus L. Koch, 1873 (Neobisiidae, Pseudoscorpiones), from East Serbia. Mém. Biospéléol., 18: 163-168.

Curčić, B.P.M., 1992a. New and little-known pseudoscorpions of the genus Roncus L. Koch (Neobisiidae, Pseudoscorpiones) from Serbia, Yugoslavia. Bijdr. Dierk., 61 (4): 237-249.

Curcić, B.P.M., 1992b. A new species of Roncus L. Koch, 1873, from southeastern Europe (Pseudoscorpiones: Neobisiidae). Proc. entomol. Soc. Wash., 94(4): 447-453.

Curčić, B.P.M. \& P. Beron, 1981. New and little-known cavernicole pseudoscorpions in Bulgaria (Neobisiidae, Pseudoscorpiones, Arachnida). Glasn. srpsk. Akad. Nauka, Beograd, 329; Cl. Sci. Nat.-Math., 48: 63-85.

Curčić, B.P.M., R.N. Dimitrijević \& O.S. Karamata, 1992. A revision of some species of Roncus L. Koch (Neobisiidae, Pseudoscorpiones) from North America and South Europe. J. Arachnol., 20(2): 114-128.

Stratimirović, Dj., 1936. O nekim narodnim pesmama paganskog porekla. God. mat. Srpske, Novi Sad, 1936: 139150.

Received: 6 May 1992. 